\title{
ANEMIA IBU HAMIL PADA PEROKOK PASIF DI WILAYAH PUSKESMAS KOTA BANJARMASIN TAHUN 2016.
}

\author{
Hapisah, S.Si.T., MPH ${ }^{1}$, Tri Tunggal, SPd, S.S.T.,MSc ${ }^{2}$ \\ 1,2) Poltekkes Kemenkes Banjarmasin Jurusan Kebidanan \\ Email: hapisah476@gmail.com, trijurbidbjm@gmail.com
}

\begin{abstract}
Anaemia in pregnancy increases the risk of complications in pregnancy and childbirth, e.i. maternal death, prematurity, LBW, and perinatal mortality. Many factors cause anaemia, including when pregnant woman got exposure from tar, free radicals and carbonmonoxide contained in cigarette smoke that is inhaled directly by unintentionally. $\mathrm{CO}$ is directly bound in maternal hemoglobin so the ability of hemoglobin to be much greater binds $\mathrm{CO}$ than oxygen. Inhaling tobacco smoke in passive smoking, has far lower levels of folic acid, exposure to acid smoking causes a disruption of iron metabolism in red bloodcells. Iron very useful in the formation of hemoglobin, deficiencies of folic acid and iron can cause defects in the fetus and anaemia. Research purpose to know the incidence of anaemia in pregnant women passive smokers in Banjarmasin City Health Center 2016. Research method uses a case control study design. Population is all pregnant women in Banjarmasin City Health Center 2016. Samples were 120 people, composed of 60 cases pregnant women anaemia, and control were 60 pregnant women anaemia which doesn't meet the criteria of inclusion and exclusion. Results showed 36 pregnant women were exposed to cigarette smoke, 24 respondents $(40 \%)$ had a case group and 12 respondents $(20 \%)$ in control group. There is a meaningful relationship between pregnant women passive smokers with incidence of anemia, value of $\mathrm{p}=0.0280 .05$ and OR $\alpha<2.67$ (CI6.034 1.178). Exposure to cigarette smoke are at risk of 2.67 times against the incidence of anaemia pregnant woman than not exposed.
\end{abstract}

Keywords: passive smokers, anemia in pregnancy

Copyright (C) 2019 Jurnal Skala Kesehatan. Politeknik Kesehatan Banjarmasin All rights reserved

Corresponding Author :

Hapisah,

Poltekkes Kemenkes Banjarmasin Jurusan

Kebidanan Jln H. Mistar Cokrokusumo

Banjarbaru

Email : hapisah476@gmail.com 


\begin{abstract}
Abstrak: Anemia pada ibu hamil meningkatkan risiko komplikasi kehamilan dan persalinan, yaitu risiko kematian maternal, angka prematuritas, BBLR, dan angka kematian perinatal. Banyak faktor yang menjadi penyebab terjadinya anemia, diantaranya apabila seorang wanita hamil mendapat paparan dari tar, radikal bebas dan karbonmonoksida yang terdapat dalam asap rokok yang dihirup langsung dengan tidak sengaja (perokok pasif). Karbonmonoksida secara langsung diikat dalam haemoglobin ibu sehingga kemampuan haemoglobin akan jauh lebih besar mengikat $\mathrm{CO}$ dari pada mengikat oksigen. Menghirup asap tembakau terutama pada perokok pasif memiliki kadar asam folat jauh lebih rendah, paparan asam rokok menyebabkan gangguan metabolisme zat besi dalam sel darah merah. Zat besi sangat berguna dalam pembentukan hemoglobin sehingga difesiensi asam folat dan zat besi dapat menimbulkan kecacatan pada janin dan mengakibatkan anemia. Tujuan penelitian mengetahui kejadian anemia pada ibu hamil perokok pasif di wilayah Puskesmas Kota Banjarmasin Tahun 2016. Metode penelitian menggunakan rancangan case control study. Populasi seluruh ibu hamil di wilayah Puskesmas Kota Banjarmasin Tahun 2016. Sampel sebanyak 120 orang, terdiri dari kasus 60 orang ibu hamil anemia, dan kontrol sebanyak 60 orang ibu hamil tidak anemia yang memenuhi kriteria inklusi dan eksklusi. Hasil penelitian didapatkan sebanyak 36 orang ibu hamil terpapar asap rokok, 24 orang responden (40\%) terdapat kelompok kasus dan 12 orang responden (20\%) pada kelompok kontrol. Ada hubungan bermakna antara ibu hamil perokok pasif dengan kejadian anemia dengan nilai $\mathrm{p}=0.028<\alpha 0,05$ dan OR 2.67 (CI 1.178-6.034). Paparan asap rokok berisiko 2.67 kali terhadap kejadian anemia ibu hamil dibanding tidak terpapar asap rokok.
\end{abstract}

Kata Kunci : perokok pasif, anemia pada kehamilan

\title{
PENDAHULUAN
}

Anemia merupakan salah satu masalah yang dialami oleh wanita hamil di seluruh dunia, terutama di negara berkembang. Menurut World Health Organitation (WHO) diperkirakan prevalensi anemia pada kehamilan di dunia adalah sebesar 55\% dan cenderung meningkat sesuai dengan bertambahnya usia kehamilan. Sedangkan di Indonesia terdapat sebanyak $37,1 \%$ dengan proporsi yang hampir sama antara di kawasan perkotaan $(36,4 \%)$ dan perdesaan (37,8\%) (Riswan. M, 2003; Riskesdas 2013).

Anemia adalah suatu keadaan adanya penurunan kadar hemoglobin $(\mathrm{Hb})$, hematokrit, dan atau jumlah eritrosit dibawah nilai normal. Menurut WHO Kriteria anemia pada kehamilan adalah $\mathrm{Hb}$ kurang dari $11 \mathrm{gr} / \mathrm{dl}$ sedangkan menurut The centers for Disease Control and Prevention (CDC) menyebutkan kriteria anemia adalah $\mathrm{Hb}$ kurang dari $11 \mathrm{gr} / \mathrm{dl}$ untuk trimester I dan III, serta Hb kurang dari 10,5 gr/dl untuk trimester II (Cunningham, 2005).

Anemia pada kehamilan berhubungan dengan meningkatnya kesakitan dan kematian ibu dan bayi yang akan dilahirkan. Pada saat kehamilan komplikasi yang ditimbulkan diantaranya dapat mengakibatkan abortus, persalinan prematur, hambatan tumbuh kembang janin dalam rahim, mudah terjadi infeksi, juga dapat mengakibatkan perdarahan antepartum dan ketuban pecah dini. Sedangkan saat persalinan terjadinya perdarahan antepartum dan postpartum lebih sering dijumpai pada wanita yang anemis 
dan lebih sering berakibat fatal, sebab wanita anemis tidak dapat mentolerir kehilangan darah. WHO menyatakan bahwa $40 \%$ kematian ibu-ibu di negara berkembang berkaitan dengan anemia pada kehamilan (Nina Herlina dan Fauzia Djamilus, 2006; Manuaba, 2007).

Penyebab anemia pada ibu hamil diperkirakan sekitar 70\% karena defisiensi zat besi, hal ini karena kurangnya asupan zat besi dan protein dari makanan, adanya gangguan absorbsi di usus, perdarahan akut maupun kronis, dan meningkatnya kebutuhan zat besi. Badan kesehatan dunia (WHO) melaporkan bahwa prevalensi ibu-ibu hamil yang mengalami defisiensi zat besi sekitar $35-75 \%$, serta semakin meningkat seiring dengan pertambahan usia kehamilan (Ridwan, 2004; Cunningham, 2005).

Menurut laporan hasil Riset Kesehatan Dasar (Riskesdas) Nasional tahun 2007 menjabarkan prevalensi anemia dari 33 provinsi yang diketahui bahwa sebanyak 20 provinsi memiliki angka prevalensi anemia yang lebih besar daripada angka rata-rata Indonesia, salah satunya adalah di pulau Kalimantan yaitu Kalimantan Barat $11.9 \%$, Kalimantan Tengah 12.7\%, Kalimantan Selatan 10.9\%, dan Kalimantan Timur 13.9\%.

Target ambang batas kejadian anemia di kota Banjarmasin sebesar $15 \%$, untuk mencapai target tersebut salah satunya ialah dengan cara pembagian tablet besi (Fe1 dan Fe3). Cakupan pemberian Fe1 dan Fe3 pada ibu hamil di kota Banjarmasin telah memenuhi target $90 \%$, demikian juga dengan cakupan untuk masing-masing kecamatan telah memenuhi target. Hasil cakupan tablet besi pada tahun 2014 pemberian Fe 1 pada ibu hamil mencapai 95,16\% dan Fe 3 94,14\%. Pada tahun 2015 terjadi penurunan cakupan pemberian tablet besi yaitu menjadi 89,91\% cakupan pemberian Fe1 dan 80,04\% cakupan pemberian Fe3. Upaya pemeberian fe sudah dilakukan, akan tetapi masih temukan beberapa puskesmas dengan cakupan $\geq$ anemia lebih $20 \%$ yaitu Puskesmas Alalak Selatan, Alalak Tengah dan Kelayan Timur, Gadang Hanyar, Sei Jingah dan Sei Mesa (Profil Dinkes Kota Banjarmasin, 2015).

Beberapa diantara faktor-faktor yang dapat menyebabkan anemia adalah keberadaan asap rokok yang dihirup langsung dengan sengaja (perokok aktif) atau tidak sengaja (perokok pasif) oleh seseorang. Populasi yang sangat rentan terhadap asap rokok adalah ibu hamil karena mereka menghirup udara lebih sering dari suami atau anggota keluarga yang merokok yang tinggal serumah. Apabila seorang ibu hamil terpapar asap rokok berisiko terjadinya penurunan kadar hemoglobin karena asap yang dihirup sebagai perokok pasif mengandung adanya tar dan radikal bebas yang dapat mengakibatkan kerusakan sumsum tulang sehingga menyebabkan hemolisis sel darah merah. Selain itu, paparan dari karbonmonoksida (CO) dapat secara langsung diikat dalam haemoglobin ibu sehingga kemampuan haemoglobin akan jauh lebih besar mengikat $\mathrm{CO}$ dari pada mengikat oksigen. Menghirup asap tembakau terutama pada perokok pasif (environmental tobacco smoke) memiliki kadar asam folat jauh lebih rendah daripada perokok aktif. (Nakamura, et al., 2004)

Menurut Hong, et al., (2007) paparan asap rokok dapat mengakibatkan gangguan metabolisme zat besi dalam sel darah merah. Zat besi sangat berguna dalam pembentukan hemoglobin sehingga difesiensi asam folat dan zat besi dapat menimbulkan kecacatan pada janin dan mengakibatkan anemia. Ibu yang tidak merokok dan terpapat ETS meningkatkan risiko terjadinya anemia (Goel. P, et al., 2004).

Sebanyak 85\% asap yang dihirup perokok pasif berasal dari asap yang dihembuskan oleh perokok aktif dibandingkan asap rokok yang berasal dari pembakaran rokok. Asap rokok yang dihasilkan dari perokok aktif mengandung lebih banyak bahan berbahaya dengan konsentrasi yang lebih tinggi dibandingkan asap yang dihirup perokok aktif dari rokoknya sendiri. Sehingga diklasifikasikan sebagai 'Class A Carcinogen' sejajar dengan 
asbes, arsenik, benzena, dan gas radon yang dapat menyebabkan kanker (Goel. P, et al., 2004, hal.12)

Asap rokok memuat 4000 senyawa kimia, 200 di antaranya toksik (beracun), $43 \mathrm{di}$ antaranya bersifat karsinogenik (dapat menyebabkan kanker). Perokok pasif lebih banyak menghirup karbon monoksida (CO) yakni 5 kali, benzopiren3 kali, dan amoniak 50 kali lebih banyak daripada perokok aktif (Mangoenprasodjo \& Hidayati, 2005). Di Indonesia merokok menempati urutan ketiga setelah China dan India. Lebih dari setengah (57\%) rumah tangga mempunyai sedikitnya satu perokok dan hampir semuanya (91.8\%) merokok di dalam rumah sehingga anggota keluarga yang tidak merokok tapi ikut terpapar asap rokok (Wiro, 2009).).

Berdasarkan studi pendahuluan yang dilakukan di 3 (tiga) Puskesmas Kota Banjarmasin dengan angka kejadian anemia $>20 \%$ yang yaitu Puskesmas Puskesmas Alalak Tengah Gadang Hanyar dan Sei Jingah tehadap 10 ibu hamil yang berkunjung didapatkan data $40-60 \%$ terpapar asap rokok secara langsung di dalam rumah dengan jumlah 3-8 batang rokok per hari. Berdasarkan data dan hasil wawancara maka penulis terarik untuk mengetahui hubungan antara perokok pasif dengan kejadian anemia pada ibu hamil di wilayah Puskesmas Kota Banjarmasin Tahun 2016.

\section{BAHAN DAN METODE}

Metode dengan desain matched case control study. Kasus adalah ibu hamil anemia dan kontrol ibu hamil tidak anemia yang kedua kelompok tersebut terpaparan asap rokok pada kehamilan sebelumnya. Penelitian dilaksanakan di wilayah Puskesmas Kota Banjarmasin yaitu Puskesmas Alalak Selatan, Alalak Tengah,Kelayan Timur, Gadang Hanyar, Sei Jingah dan Sei Mesa. Sampel penelitian adalah ibu hamil trimester III yang terdiri dari sampel kasus dan sampel kontrol sebanyak 120 orang yang memenuhi kriteria inklusi diantaranya usia Ibu 20 - 35 tahun, jarak kehamilan > 2 tahun, Paritas 1-3, mendapatkan tablet Fe 90 tablet. Sedangkan kiteria eksklusinya sebagai berikut ibu hamil dengan komplikasi penyakit kronis: TBC, ibu hamil dengan Lila $<23,5 \mathrm{~cm}$, ibu hamil dengan komplikasi perdarahan sedang dalam perawatan dokter. Teknik pengambilan sampel non probability sampling dengan metode consecutive sampling besar sampel kontrol dengan rasio 1:1.Instrumen yang dipergunakan dalam pengumpulan data adalah angket/kuesioner dan data yang terkumpul dilakukan dianalisis dengan uji Chi Squar .

\section{HASIL DAN PEMBAHASAN}

a. Pendidikan

Tabel 1 Distribusi Frekuensi Subjek Penelitian Berdasarkan Pendidikan dan Pekerjaan Pada Kelompok Kasus dan Kontrol di Puskesmas Wilayah Kota Banjarmasin Tahun 2016

\begin{tabular}{lcccccc}
\hline \multirow{2}{*}{ Karakteristik } & \multicolumn{9}{c}{ Status Gizi } & \multirow{2}{*}{ Kontrol } & $\mathbf{1 4 0}$ & \multirow{2}{*}{$(\%)$} \\
\cline { 2 - 5 } & $\mathbf{6 0}$ & $\mathbf{( \% )}$ & $\mathbf{6 0}$ & $\mathbf{( \% )}$ & & \\
\hline Pendidikan & & & & & & \\
Dasar & 36 & 60.0 & 28 & 46.7 & 64 & 53.3 \\
Menengah & 17 & 28.3 & 27 & 45.0 & 44 & 36.7 \\
Tinggi & 7 & 11.1 & 5 & 8.3 & 12 & 10.0 \\
Pekerjaan & & & & & & \\
Bekerja & 10 & 16.7 & 11 & 18.3 & 21 & 17.5 \\
Tidak Bekerja & 50 & 83.3 & 49 & 81.7 & 99 & 82.5 \\
\hline
\end{tabular}


tabel 1 dari 60 responden pada kelompok kasus terdapat sebanyak 36 orang responden $(60 \%)$ dengan pendidikan dasar dan pada kelompok kontrol hanya 5 orang responden $(8.3 \%)$ berpendidikan tinggi. Sebagian besar status pekerjaan ibu adalah ibu rumah tangga (tidak bekerja) yaitu sebanyak 99 orang $(82.5 \%)$ dan terdapat sebanyak 10 orang responden $(16,7 \%)$ bekerja pada kelompok kasus.

b. Kebiasaan Merokok Anggota Keluarga :

Tabel 2 Distribusi Frekuensi Berdasarkan Status Merokok Anggota Keluarga Yang Tinggal Serumah Dengan Ibu Hamil di Puskesmas Wilayah Kota Banjarmasin Tahun 2016.

\begin{tabular}{lllllll}
\hline \multirow{2}{*}{ Staus } & \multicolumn{9}{c}{ Status Gizi } & \multirow{2}{*}{ Kasus } & \multicolumn{2}{c}{ Kontrol } & \multirow{2}{*}{$\mathbf{( \% )}$} \\
\cline { 2 - 5 } & $\mathbf{6 0}$ & $\mathbf{( \% )}$ & $\mathbf{6 0}$ & $(\mathbf{\%})$ & & \\
\hline Merokok & 31 & 51.7 & 18 & 30.0 & 49 & 40.8 \\
Tidak Merokok & 29 & 48.3 & 42 & 70.0 & 71 & 59.2 \\
\hline
\end{tabular}

tabel 2 menunjukkan persentasi kelompok ibu hamil dengan anemia 1.1 kali lebih banyak memiliki anggota keluarga yang merokok di banding tidak merokok. Kelompok kasus terdapat sebanyak 31 orang responden $(51,7 \%)$ memiliki anggota keluarga merokok dan pada kelompok kontrol 42 orang responden $(70 \%)$ tidak memiliki anggota keluarga merokok.

c. Lokasi Merokok dan Jumlah Batang Rokok

Tabel 3 Distribusi Frekuensi Berdasarkan Lokasi Merokok dan Jumlah Batang Rokok Anggota Keluarga Pada Kelompok Kasus dan Kontrol di Puskesmas Wilayah Kota Banjarmasin Tahun 2016.

\begin{tabular}{lccccccc}
\hline \multirow{2}{*}{$\begin{array}{l}\text { Anggota Keluarga } \\
\text { Merokok }\end{array}$} & \multicolumn{9}{c}{ Status Gizi } & \multirow{2}{*}{ Kasus } & \multirow{2}{*}{ Kontrol } & \\
\cline { 2 - 5 } & $\mathbf{3 0}$ & $\mathbf{( \% )}$ & $\mathbf{1 9}$ & $\mathbf{( \% )}$ & & \\
\hline Lokasi Merokok & & & & & & \\
Dalam Rumah & 20 & 66.7 & 8 & 42.1 & 28 & 57.1 \\
Diluar Rumah & 10 & 33.3 & 11 & 57.9 & 21 & 42.9 & \\
Jmh Btg Rokok & & & & & & & \\
< 12 Batang & 26 & 86.7 & 16 & 84.2 & 42 & 85.7 & Berda \\
12- 24 Batang & 3 & 10.0 & 3 & 15.8 & 6 & 12.2 & sarka \\
>24 Batang & 1 & 3.3 & 0 & 0.0 & 1 & 2.0 & n \\
\hline
\end{tabular}

tabel 3 dari 30 responden pada kelompok kasus terdapat sebanyak 20 orang responden $(66.7 \%)$ merokok didalam rumah dan pada kelompok kontrol hanya 8 orang responden (28\%) merokok didalam rumah. Sedangkan jumlah dari batang rokok yang di isap pada kelompok kasus terdapat sebanyak 26 orang responden $(86.7 \%)$ merokok $<12$ batang dan hanya 1 orang responden (3.3\%) yang meroko $>24$ batang rokok. 
d. Kebiasaan Merokok Teman Sekerja

Tabel 4 Distribusi Frekuensi Berdasarkan Kebiasaan Merokok Teman Sekerja Ibu Hamil Pada Kelompok Kasus dan Kontrol di Puskesmas Wilayah Kota Banjarmasin Tahun 2016.

\begin{tabular}{|c|c|c|c|c|c|c|}
\hline \multirow{3}{*}{ Teman Sekerja } & \multicolumn{4}{|c|}{ Status Gizi } & \multirow{3}{*}{120} & \multirow{3}{*}{$(\%)$} \\
\hline & \multicolumn{2}{|c|}{ Kasus } & \multicolumn{2}{|c|}{ Kontrol } & & \\
\hline & 60 & $(\%)$ & 60 & $(\%)$ & & \\
\hline Merokok & 4 & 6.7 & 5 & 8.3 & 9 & 7.5 \\
\hline Tidak Merokok & 56 & 93.3 & 55 & 91.7 & 111 & 92.5 \\
\hline
\end{tabular}

tabel 4 dari 60 responden pada kelompok kasus terdapat sebanyak 4 orang responden (6.7\%) merokok dengan teman sekerja dan pada kelompok kontrol 55 orang responden $(91.7 \%)$ tidak merokok dengan teman sekerja.

e. Lokasi Merokok Teman Kerja

Lokasi merokok teman sekerja adalah lokasi yang biasa dilakukan teman sekerja dengan ibu hamil yang bekerja.

Tabel 5 Distribusi Frekuensi Berdasarkan Lokasi Merokok Teman Kerja Pada Kelompok Kasus dan Kontrol di Puskesmas Wilayah Kota Banjarmasin Tahun 2016.

\begin{tabular}{lcccccc}
\hline \multirow{2}{*}{ Lokasi Merokok } & \multicolumn{4}{c}{ Status Gizi } & \multirow{2}{*}{ Kasus } & \multicolumn{2}{c}{ Kontrol } & \multirow{9}{*}{$(\boldsymbol{\%})$} \\
\cline { 2 - 5 } & $\mathbf{5}$ & $\mathbf{( \% )}$ & $\mathbf{4}$ & $\mathbf{( \% )}$ & & \\
\hline Dalam Ruang Kerja & 4 & 80.0 & 2 & 50.0 & 6 & 66.7 \\
Diluar Ruang Kerja & 1 & 20.0 & 2 & 50.0 & 3 & 33.3 \\
\hline
\end{tabular}

tabel 5 dari 5 responden pada kelompok kasus terdapat sebanyak 4 orang responden $(80 \%)$ merokok dalam ruang kerja dan pada kelompok kontrol hanya 2 orang responden (50\%) merokok diluar ruang kerja.

f. Analisa Univariabel :

Tabel 6 Distribusi Frekuensi Berdasarkan perokok pasif pada Kelompok Kasus dan Kontrol di Puskesmas Wilayah Kota Banjarmasin Tahun 2016.

\begin{tabular}{|c|c|c|c|c|c|c|}
\hline \multirow{3}{*}{ Ibu Hamil } & \multicolumn{4}{|c|}{ Status Gizi } & \multirow{3}{*}{140} & \multirow{3}{*}{$(\%)$} \\
\hline & \multicolumn{2}{|c|}{ Kasus } & \multicolumn{2}{|c|}{ Kontrol } & & \\
\hline & 60 & $(\%)$ & 60 & $(\%)$ & & \\
\hline Perokok Pasif & 24 & $\overline{40.0}$ & 12 & 20.0 & 36 & 30.0 \\
\hline Tidak Perokok Pasif & 36 & 60.0 & 48 & 80.0 & 84 & 70.0 \\
\hline
\end{tabular}

tabel 6 dari 60 responden pada kelompok kasus terdapat sebanyak 24 orang responden (40\%) dengan perokok pasif dan pada kelompok kontrol 48 orang responden (80\%) tidak perokok pasif. 
g. Analisa Bivariabel

Tabel 4.7 Hubungan antara Ibu Hamil Perokok Pasif dengan Status gizi Pada Kasus dan Kontrol di Puskesmas Wilayah Kota Banjarmasin Tahun 2016.

\begin{tabular}{|c|c|c|c|c|c|c|c|c|}
\hline \multirow{3}{*}{ Ibu Hamil } & \multicolumn{4}{|c|}{ Status Gizi } & \multirow{3}{*}{120} & \multirow{3}{*}{$(\%)$} & \multirow{3}{*}{ OR } & \multirow{3}{*}{ CI } \\
\hline & \multicolumn{2}{|c|}{ Kasus } & \multicolumn{2}{|c|}{ Kontrol } & & & & \\
\hline & 60 & $(\%)$ & 60 & $(\%)$ & & & & \\
\hline Perokok Pasif & 24 & $\begin{array}{c}40 . \\
0\end{array}$ & 12 & $\begin{array}{c}20 . \\
0\end{array}$ & 36 & $\begin{array}{c}30 . \\
0\end{array}$ & 2.6 & $1178-6034$ \\
\hline Tidak Perokok Pasif & 36 & $\begin{array}{c}60 . \\
0\end{array}$ & 48 & $\begin{array}{c}80 . \\
0\end{array}$ & 84 & $\begin{array}{c}70 . \\
0\end{array}$ & 7 & $1.1 / 8-0.034$ \\
\hline
\end{tabular}

tabel 4.9 pada ibu kelompok hamil dengan perokok pasif memiliki hubungan yang signifikan terhadap kejadian anemia dengan nilai $p=0.028<<\alpha 0,05$ dan OR 2.67 ( CI 1.178-6.034). hal ini menunjukkan bahwa ibu hamil dengan paparan asap rokok (perokok pasif) beisiko terhadap kejadian anemia 2.67 kali dibanding dengan ibu hamil yang tidak terpapar asap rokok.

1. Perokok Pasif (environmental tobacco smoke)

Perokok pasif adalah paparan asap tembakau yang disebarkan ke udara bebas yang akan dihirup oleh orang disekitar perokok di dalam rumah maupun di tempat kerja.Berdasarkan hasil penelitian yang terdapat pada tabel 4.6 terdapat sebanyak 24 orang responden (40\%) ibu hamil trimester III dengan anemia mendapatkan paparan asap rokok (perokok pasif). Sedangkan pada ibu yang tidak mengalami anemia terdapat 48 orang responden $(80 \%)$ tidak mendapat paparan asap rokok (perokok pasif). Paparan asap rokok didapatkan $40 \%$ dari lingkungan keluarga dan 7,5\% dari lingkungan kerja. Ibu hamil adalah populasi yang sangat rentan terhadap paparan asap rokok karena mereka menghirup udara lebih sering dari suami atau anggota keluarga yang merokok yang tinggal serumah maupun dari teman sekerja.

Banyak bahan kimia yang terkandung di dalam asap rokok dan hampir kesemua dari bahan kimia ini mempunyai efek negatif terhadap fisiologi tubuh. Menurut Mangoenprasodjo \& Hidayati (2005), asap rokok memuat 4000 senyawa kimia, 200 di antaranya toksik (beracun), 43 di antaranya bersifat karsinogenik (dapat menyebabkan kanker). Perokok pasif lebih banyak menghirup karbon monoksida (CO) yakni 5 kali, benzopiren3 kali, dan amoniak 50 kali lebih banyak daripada perokok aktif.

Berdasarkan lokasi merokok yang biasa dilakukan anggota keluarga yang tinggal serumah dengan ibu hamil didapatkan sebanyak 57.1\% kebiasaan merokok dilakukan di dalam dan ibu hamil yang bekerja didapatkan sebanyak $66.7 \%$ mendapatkan paparan asap rokok di ruangan kerja. Penelitian yang berkaitan dengan kebiasaan anggota keluarga merokok di dalam rumah dilakukan oleh Isnaini, dkk (2013) didapatkan sebanyak $77,1 \%$ anggota keluarga merokok didalam rumah dan menurut depkes RI, (2009) hampir semuanya (91.8\%) merokok di dalam rumah sehingga anggota keluarga yang tidak merokok tapi ikut terpapar asap rokok.

Sedangkan jumlah dari batang rokok yang di isap pada kelompok kasus terdapat sebanyak 26 orang responden $(86.7 \%)$ merokok $<12$ batang dan hanya 1 orang responden $(3.3 \%)$ yang meroko $>24$ batang rokok. 
2. Hubungan Perokok Pasif Dengan Kejadian Anemia

Penelitian ini menunjukkan bahwa ibu hamil dengan perokok pasif memiliki hubungan yang signifikan dengan kejadian anemia dengan nilai $p=0.028<\alpha 0,05$ dan OR 2.67 ( CI 1.178-6.034). Ibu hamil perokok pasif lebih banyak terjadi pada pada kelompok ibu yang mengalami anemia dibanding dengan ibu hamil tidak dengan anemia. Ibu hamil dengan paparan asap rokok (perokok pasif) beisiko terhadap kejadian anemia 2.67 kali dibanding dengan ibu hamil yang tidak terpapar asap rokok. Hasil penelitian ini sejalan dengan penelitian Goel. P, et al (2004) Ibu merokok dan terpapat ETS meningkatkan risiko terjadinya anemia.

Merokok tidak hanya berbahaya pada perokok sendiri, akan tetapi pda orang lain yang menhirup asap samping (side stream smoke) yaitu asap tembakau yang disebarkan ke udara bebas yang banyk mengandung senyawa kimia yang membahayakan terutama pada ibu hamil.

Mekanisme terjadinya anemia pada ibu hamil perokok pasif Menurut Hong, et al., (2007) disebabkan karena paparan asap rokok mengandung gas CO yang mempunyai kemampuan lebih kuat mengikat haemoglobin $(\mathrm{Hb})$ yang terdapat dalam sel darah merah (eritrosit). CO adalah sejenis gas tidak memiliki bau yang dihasilkan oleh pembakaran tidak sempurna dari unsur zat arang atau karbon. Sebatang rokok dapat menghasilkan $3-6 \%$ gas $\mathrm{CO}$, gas ini dapat di hisap oleh orang yang merokok atau orang yang terdekat dengan si perokok, atau orang yang berada dalam satu ruangan. Seorang yang merokok hanya akan menghisap $1 / 3$ bagian saja melalui asap utama (main-stream), sedangkan asap samping 2/3 (side - stream) akan tetap berada diluar. Paparan asap rokok dapat mengakibatkan gangguan metabolisme zat besi dalam sel darah merah. Zat besi sangat berguna dalam pembentukan hemoglobin sehingga difesiensi asam folat dan zat besi dapat menimbulkan kecacatan pada janin dan mengakibatkan anemia.

Penelitian Wulandari, dkk (2010) pada tikus putih jantan galur wistar menyimpulkan paparan asap rokok dapat menyebabkan penurunan jumlah eritrosit dan kadar hemoglobin. Hal tersebut dijelaskan karena komponen dalam asap rokok yang utama adalah tar, nikotin, karbonmonoksida (CO) dan radikal bebas serta timbal dapat menyebabkan kerusakan pada sumsum tulang (organ yang memproduksi eritrosit). Kandungan tar yang tinggi dapat merusak sumsum tulang (pembentuk sel darah merah, nikotin dapat menyempitkan pembuluh darah sehingga meningkatkan tekanan darah dan viskositas darah sedangkan $\mathrm{CO}$ dapat menyebabkan hipoksia jaringan serta radikal bebas dapat menyebabkan hemolysis sel darah merah. Adanya timbal dalam darah dapat mengganggu biosintesa heme sehingga menyebabkan kadar hemoglobin rendah, dan disebut sebagai anemia.

Asap rokok juga mengandung nikotin antara $0,5-3 \mathrm{ng}$ dan semuanya diserap sehingga di dalam cairan darah atau plasma antara $40-50 \mathrm{ng} / \mathrm{ml}$. Nikotin bukan merupakan komponen karsinogenik akan tetapi pembusukan panas dari nikotin seperti dibensakridin, dibensokarbasol, dan nitrosamin-lah yang bersifat karsinogenik. Nikotin memiliki karakteristik efek adiktif dan psikoaktif sehingga perokok akan merasakan kenikmatan, kecemasan berkurang, toleransi dan keterikatan fisik yang membuat perokok susah berhenti. Efek nikotin meningkatkan rangsangan hormon adrenalin (kathekolamin) yang bersifat memacu jantung dan tekanan darah, sehingga seseorang yang terpapar nikotin dapat berakibat timbulnya hipertensi. Efek lain merangsang berkelompoknya trombosit (sel pembekuan darah), trombosit akan menggumpal dan akhirnya akan menyumbat pembuluh darah yang sudah sempit akibat asap yang mengandung $\mathrm{CO}$ yang berasal dari rokok. 
Selain zat diatas, asap rokok juga mengandung tar yaitu sejenis cairan kental berwarna coklat tua atau hitam yang merupakan substansi hidrokarbon yang bersifat lengket dan menempel pada paru-paru. Kadar tar pada rokok antara 0,5-35 mg per batang. Tar merupakan suatu zat karsinogen yang dapat menimbulkan kanker pada jalan nafas dan paru-paru. Kadmium adalah zat yang dapat meracuni jaringan tubuh terutama ginjal, amoniak merupakan gas yang tidak berwarna yang terdiri dari nitrogen dan hydrogen. Zat ini tajam baunya dan sangat merangsang. Begitu kerasnya racun yang ada pada ammonia sehingga jika masuk sedikit pun ke dalam peredaran darah akan mengakibatkan seseorang pingsan atau koma. Selain itu, hidrogen sianida merupakan sejenis gas yang tidak berwarna, tidak berbau dan tidak memiliki rasa. Zat ini merupakan zat yang paling ringan, mudah terbakar dan sangat efisien untuk menghalangi pernapasan dan merusak saluran pernapasan. Sianida adalah salah satu zat yang mengandung racun yang sangat berbahaya. Sedikit saja sianida dimasukkan langsung ke dalam tubuh dapat mengakibatkan kematian.

Beberapa komponen kandungan zat - zat beracun pada asap rokok diatas hanyalah sebagian kecil saja, sebenarnya asap rokok memuat 4000 senyawa kimia, 200 di antaranya toksik (beracun), 43 di antaranya bersifat karsinogenik (dapat menyebabkan kanker). Perokok pasif lebih banyak menghirup karbon monoksida (CO) yakni 5 kali, benzopiren3 kali, dan amoniak 50 kali lebih banyak daripada perokok aktif.

\section{KESIMPULAN}

Dari 120 orang Ibu Hamil Trimester III didapatkan sebanyak 36 orang responden terpapar asap rokok (perokok pasif). Sebanyak 24 orang responden (40\%) terpapar asap rokok (perokok pasif) pada kelompok kasus dan 12 orang responden (20\%) pada kelompok kontrol. Ada hubungan yang bermakna antara ibu hamil perokok perokok pasif dengan kejadian anemia dengan nilai $p=0.028$ dan OR 2.67 (CI 1.178-6.034). Paparan asap rokok beisiko 2.67 kali terhadap kejadian anemia ibu hamil dibanding dengan yang tidak terpapar asap rokok.

Diharapkan dengan adanya penelitian ini dapat meningkatkan penyuluhan akan bahaya merokok pada ibu hamil dan bayi yang dikandungnnya. Selain itu juga diharapkan ibu hamil dapat menghindari paparan asap rokok di lingkungan rumah maupun lingkungan tempat kerja

\section{UCAPAN TERIMAKASIH}

Penyelesaian laporan penelitian ini telah banyak menerima bantuan dari berbagai pihak, untuk itu pada kesempatan ini penulis mengucapkan terima kasih kepada Direktur, Ketua Jurusan Kebidanan dan Ka Unit PPM Politeknik Kesehatan Kementerian Kesehatan Banjarmasin, Kepala Dinas Kesehatan Kota Banjarmasin, dan seluruh responden yang bersedia berpartisipasi pada studi pendahuluan penelitian, serta semua pihak yang telah membantu penulisan proposal penelitian ini. Semoga Allah SWT melimpahkan rahmatNya kepada semua pihak yang telah membantu.

\section{DAPTAR PUSTAKA}

1. Riswan, Muhammad, "Anemia Defisiensi Besi Pada Wanita Hamil Di beberapa Praktek Bidan Swasta DalamKota Madya Medan," Bagian Ilmu Penyakit dalam Fakultas kedokteran Universitas Sumatera Utara, 2003.

2. Riskesdas, "Laporan Nasional 2013," Badan Penelitian dan Pengembangan Kesehatan. Departemen Kesehatan, Republik Indonesia, 2013. 
3. Cunningham, F. G., Gant, N. F., Leveno, K. J., Giltrap, L. C., Hauth, J. C., Wenstrom, K. D, "Williams obstetrics $21^{\text {st }}$ ed. Ch. 33: Spontaneous abortion," New York: Mc Graw-Hill, pp. 856-69, 2001.

4. Nina Herlina dan Fauzia Djamilus, "Faktor Risiko Kejadian Anemia pada ibu hamil di Wilayah Bogor," 2006.

5. Manuaba, I. A., dkk, "Ilmu Kebidanan, Penyakit Kandungan dan KB," EGC, Jakarta, 2010

6. Ridwan Amiruddin, Wahyuddin, "Studi Kasus KontrolFaktor Biomedis Terhadap KejadianAnemia Ibu Hamil Di Puskesmas Bantimurung,".Jurnal Medika Nusantara,Volume 25 No 2, 2004.

7. Riskesdas, "Laporan Nasional 2007" Badan Penelitian dan Pengembangan Kesehatan," Departemen Kesehatan, Republik Indonesia, 2007.

8. Dinas kesehatan kota Banjarmasin, "Profil Kota Banjarmasin," 2015.

9. Nakamura, M.U., Alexander, S.M., KuhndosSantos, J.F., deSouza, E.,Sass,N., Auritscher, B.AP., Trayna,E., Andrade, C.M., Barroso, T.,Kulay, J.L. "Obstetric and Perinatal Effects of Active and/or Passive Smoking during Pregnancy, ”Epub, 122(3), pp.94-8, 2004.

10. Goel P, Radotra A, Singh I, Aggarwal A, Dua D,” Effects Of Passive Smoking On Outcome In Pregnancy," Journal Postgrad Med . Volume 50 . Edisi 1, 2004.

11. Mangoenprasodjo, S.A., Hidayati, N.S, "Hidup Sehat Tanpa Rokok," Yogyakarta: Pradipta Publishing, 2005.

12. Wiro, "Data dan Fakta Konsumsi Rokok di Indonesia," (http:/tujuhbelas.net). Diakses tanggal 17 April 2010". 2009.

13. Isnaini, M. u., Zulfitri, R., \& Misrawati, "Pengaruh kebiasaan merokok di dalam rumah terhadap kejadian ISPA pada balita," journal.unnes.ac.id, 2012.

14. Hong, Rathavuth., Jose, A., Betancourtand., Martin., Ruiz-Beltran, "Passive Smoking As A Risk Factor Of Anemia In Young Children Aged 0-35 Months In Jordan," BMC Pediatrics. Volume 7. Edisi 16, 2007.

15. Wulandari , dkk., "Pengaruh Dosis Paparan Asap Rokok Terhadap Jumlah Eritrosit Dan Kadar Hemoglobin, Fakultas Kesehatan Masyarakat Universitas Muhammadiyah Semarang," 2010. 